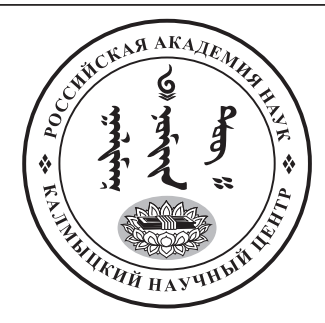

Published in the Russian Federation

Oriental Studies (Previous Name: Bulletin of the Kalmyk Institute

for Humanities of the Russian Academy of Sciences)

Has been issued as a journal since 2008

ISSN: 2619-0990; E-ISSN: 2619-1008

Vol. 13, Is. 6, pp. 1632-1640, 2020

DOI: $10.22162 / 2619-0990-2020-52-6-1632-1640$

Journal homepage: https://kigiran.elpub.ru

UDC 821.512 .36

DOI: $10.22162 / 2619-0990-2020-52-6-1632-1640$

\title{
'Booklore' Talismans in Daily Life of the Mongols: A Case Study of Two Collections of Mongolian Manuscripts
}

\author{
Anna D. Tsendina ${ }^{1}$
}

${ }^{1}$ National Research University Higher School of Economics (Bldg. 1, 21/4, Staraya Basmannaya St., Moscow 105066, Russian Federation); Kalmyk Scientific Center of the RAS (8, Ilishkin St., Elista 358000, Russian Federation)

Dr. Sc. (Philology), Professor, Leading Research Associate

iD 0000-0003-0909-6953. E-mail: annatsendina@gmail.com

(C) KalmSC RAS, 2020

(C) Tsendina A. D., 2020

\begin{abstract}
Introduction. By the beginning of the $20^{\text {th }}$ century, the Mongols had widely used texts on apotropaic magic in their daily life. Among them there are writings with pictures and descriptions of talismans aimed at averting diseases and mishaps, attracting wealth and good favour. All this sort of writings resembles heterogeneity of traditions. Goals. The paper aims at examining various types of 'booklore' talismans in magic practices of the Mongols. Results. Like other spheres of Mongolian culture those represent pre-Buddhist, Buddhist and Chinese layers. That was conditioned by the history of the Mongols, their neighbourhood with civilizations they had been integrated with during the course of their existence. As for 'booklore' talismans, there are two groups of them: one includes pictures originated from Taoist talismans, the other includes Indian and Tibetan dharanis, texts and Buddhist symbols. They penetrated into the Mongolian culture in different periods and in different ways. Thus, usage of 'booklore' talismans by the Mongols resulted in complicated multi-layer complexes which assembled Hindu, Tibetan pre-Buddhist, Mongolized Buddhist and Chinese Taoist elements in different combinations. Conclusions. The work reveals several clusters of 'booklore' talismans once popular among the Mongols and originated from pre-Buddhist, Buddhist and Taoist beliefs.
\end{abstract}

Keywords: Mongols, daily life, rites, manuscripts, talismans

Acknowledgements. The reported study was funded by government grant in the form of federal budget subsidy aimed to support scientific research directed by the Leading Scientist — project name 'From Paleogenetics to Cultural Anthropology: Comprehensive Interdisciplinary Research of Peoples and Traditions of Cross-Border Regions - Migrations, Cross-Cultural Interactions and Worldviews' (no. 075-15-2019-1879).

For citation: Tsendina A. D. 'Booklore' Talismans in Daily Life of the Mongols: A Case Study of Two Collections of Mongolian Manuscripts. Oriental Studies. 2020. Vol. 13(6): 1632-1640. (In Eng.). DOI: 10.22162/2619-0990-2020-52-6-1632-1640 
УДК 821.512 .36

DOI: $10.22162 / 2619-0990-2020-52-6-1632-1640$

\title{
«Книжные» талисманы в повседневной жизни монголов (по двум коллекциям монгольских рукописей)
}

\author{
Анна Дамдиновна Цендина ${ }^{1}$
}

${ }^{1}$ Высшая школа экономики (д. 21/4, стр. 1, Старая Басманная ул., 105066 Москва, Российская Федерация); Калмыцкий научный центр РАН (д. 8, ул. И. К. Илишкина, 358000 Элиста, Российская Федерация) доктор филологических наук, профессор, ведущий научный сотрудник

0000-0003-0909-6953. E-mail: annatsendina@gmail.com

\author{
(C) КалмНЦ РАН, 2020 \\ (C) Цендина А. Д., 2020
}

\begin{abstract}
Аннотация. Введение. До начала ХХ в. монголы широко использовали тексты по апотропической магии в своей повседневной жизни. Среди них имеются надписи с изображениями и описаниями талисманов, направленных на предотвращение болезней и несчастий, привлечение богатства и благополучия. Все эти сочинения свидетельствуют о гетерогенности традиций. Цели. Статья посвящена изучению различных типов «книжных» талисманов в магических практиках монголов. Результаты. Как и другие сферы монгольской культуры, «книжные» талисманов отражают добуддийское, буддийское и китайское влияние, что было обусловлено историей монголов, а также их соседством с цивилизациями, с которыми они контактировали. Что касается «книжных» талисманов, то их можно разделить на две группы: одна группа включает себя изображения, происходящие из даосских талисманов, другая включает индийские и тибетские дхарани, тексты и буддийские символы. «Книжные» талисманы проникли в монгольскую культуру в различное время и разными путями. Использование «книжных» талисманов монголами являлось результатом сложных многослойных комплексов, в которых в различных комбинациях соединены индуистские, тибетские добуддийские, монгольские буддийские и китайские даосские элементы. Bblводыl. В исследовании выявлены несколько групп «книжных» талисманов, когда-то популярных среди монголов и происходящих из добуддийских, буддийских и даосских верований.
\end{abstract}

Ключевые слова: монголы, повседневная жизнь, ритуалы, рукописи, талисманы

Благодарность. Исследование выполнено при финансовой поддержке гранта в форме субсидии из федерального бюджета, выделяемой для государственной поддержки научных исследований, проводимых под руководством ведущего ученого (проект № 075-15-20191879 «От палеогенетики до культурной антропологии: комплексное интердисциплинарное исследование традиций народов трансграничных регионов: миграции, межкультурное взаимодействие и картина мира»).

Для цитирования: Цендина А. Д. «Книжные» талисманы в повседневной жизни монголов (по двум коллекциям монгольских рукописей) // Oriental Studies. 2020. Т. 13. № 6. С. 1632-1640. (На англ.). DOI: 10.22162/2619-0990-2020-52-6-1632-1640

\section{Introduction}

Daily life of the Mongols, like that of any other nation, had been strictly regulated by law and traditions. In patriarchal Mongolia before the beginning of the $20^{\text {th }}$ century, traditions usually prevailed. Those were greatly conditioned by people's beliefs in transcendental forces which affected and even ruled human lives, as well as in opportunities to read their 'messages' and react against them 
through magic manipulations. There exist a number of texts on human daily routine life which include guidance about omens, fortunetelling, and averting bad luck [Banzarov 1955; Bawden 1958a; Bawden 1958b; Sazykin 1988: No. 1583-1617; Cerensodnom 1997; Gerasinova 1999; Birtalan 2003].

Among such texts there are quite many of those devoted to apotropaic magic, particularly to talismans which were to avert evil forces and mishaps, to attract prosperity and wellbeing. Most often, pictures, interpretation and directions how to use these talismans can be found in medical or rather sorcery books. While one group of 'booklore' talismans includes pictures originated from Taoist talismans, the other includes Indian and Tibetan dharani, texts and Buddhist symbols.

Below are the examples of 'booklore' talismans borrowed from the Collection of Mongolian Manuscripts and Xylographs stored at the Memorial Flat of Mongolian Academician Ts. Damdinsuren (Ulaanbaatar, Mongolia) and those from the private collection of his disciple R. Otgonbaatar (see fig. 1-3).

\section{Talismans originated from Taoist cults}

The collection of Damdinsuren's memorial flat comprises the Mongolian manuscript titled 'Fortune Telling through Light Gold Looking Glass to Clarify Good and Evil Signs' 1 [Bilguudei, Otgonbaatar, Tsendina 2018: No. 914]. This manuscript is anonymous and supposedly dates back to the $18^{\text {th }}-19^{\text {th }}$ centuries. It contains many pictures of talismans originated from Taoist symbols. It is close to treaties about omens on animals appearances and behavior, and are based on Chinese traditions. Below are guiding inscriptions how to use the pictures.

1. (4a) If a camel a horse or a cow is born mutant, hang this talisman above your dwelling. ${ }^{2}$

2. (4a) This talisman annihilates all evil omens coming from animals. ${ }^{3}$

3. (5b) It is a protective talisman if a camel, a horse or a cow is born mutant. ${ }^{4}$

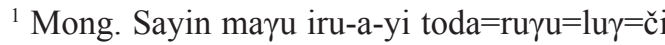
gegen öngge-tü altan toli kemekü üj̆elge oru=siba.

2 Mong. temege mori üker akiyadlabasu ger degere keyisge.

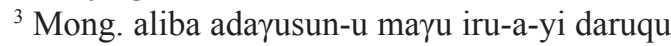
vuu.

${ }^{4}$ Mong. mori üker luusa elǰige akiyadalbasu daruqu vuu ene bui.
5. (7b) Two talismans preventing from cattle loss. ${ }^{5}$

6. (7b) It is a talisman for cow's horns. ${ }^{6}$

8. (7b) If a cow 7 times jumps upon your dwelling, put this talisman in the distinguished part of it. ${ }^{7}$

9. (8b) It is a talisman for sheep. ${ }^{8}$

11. (9a) Write the talisman for sheep and open the roll. ${ }^{9}$

12. (9a) It's a talisman to annihilate signs from sheep and pigs (?), open it. ${ }^{10}$

13. (9a) If a dog climbs upon your dwelling, it's a bad sign. Use paper to make a dog, go as far as 18 steps and throw it away together with the skin (?), 3 pieces of white silk, 1 cup of water, decorate it with 10 threads. Write the talisman and perform an averting rite. Here is the talisman. ${ }^{11}$

14. (11a) Four talismans to annihilate evil sings coming from dogs. ${ }^{12}$

15. (11a) It is a talisman [to annihilate evil omens coming] from pigs. ${ }^{13}$

17. (11a) It is a talisman [to annihilate evil omens coming] from cats. ${ }^{14}$

19. (11b) It is a talisman [to annihilate evil omens coming] from hens and ducks. ${ }^{15}$

21. (11b) Three talismans [to annihilate evil omens coming] from all wild and domestic animals. ${ }^{16}$

22. (12b) This talisman is [against omens coming] from horses. Stick it on the place of deformity. ${ }^{17}$

23. (13b) It is a talisman for common

${ }^{5}$ Mong. ükerün üküli jasa=qu qoyar jüil vuu ene.

${ }^{6}$ Mong. ükerün eber-tü kikü vuu.

${ }^{7}$ Mong. üker ger degere 7 ta qarayi $\gamma$ san-i vuu qoyimara jegüü.

${ }^{8}$ Mong. qonin-u vuu ene bui.

${ }^{9}$ Mong. qonin-u-yin vuu-yi bičijü delge.

${ }^{10}$ Mong. qoni yaqai-yin iru-a qari $\gamma u l q u$ vuu-yi (?) tu inu delge.

${ }^{11}$ Mong. noqai ger-tür abirabasu mayu čayasuniyar noqai kijü <нрзб > arisu 3 čayan tor $\gamma$-a 1 aya $\gamma$-a

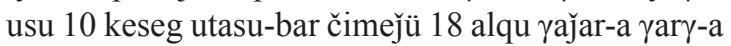
vuu bičijü qariłul : vuu inu ene bui.

12 Mong. noqai-yin aliba mayu iru-a-yi qariүulaqu-yin dörben jüil bui.

${ }^{13}$ Mong. yaqai-yin vuu ene bui.

${ }^{14}$ Mong. mii-yin vuu ene bui.

${ }^{15}$ Mong. takiy-a nurusun-u vuu ene bui.

${ }^{16}$ Mong. aliba ariyatan görügesün-ü vuu ene 3 bui.

${ }^{17}$ Mong. mori-yin vuu ene bui akiyadqalaysan yajara na $\gamma$-a. 
dwelling. ${ }^{18}$ It is a talisman for dwelling and property. ${ }^{19}$ It's a talisman of fire. ${ }^{20}$

26. (13b) If harm comes from a burhanprotector of any home, pay respect to him using white fragrance, raisins, dates, fruit and food, give prayer to the Gloss Sandal. This is a talisman. ${ }^{21}$ It is a talisman of burhan. ${ }^{22}$

27. (14a) Write a talisman for birds and tie it up to your body. ${ }^{23}$

28. (14a) It is a talisman annihilating bad signs. ${ }^{24}$

30. (14b) Write the talisman and avert. ${ }^{25}$

31. (15a) These are six types of talismans against [omens coming from] all birds. ${ }^{26}$

32. (15a) It is a talisman annihilating bad signs coming from ravens, owls and magpies. ${ }^{27}$

34. (15b) It is a talisman annihilating evil coming from birds. ${ }^{28}$

36. (16a) It is a talisman against teeth creak..$^{29}$

38. (16a) This is a talisman annihilating bad signs coming from urine. ${ }^{30}$

39. (16b) Wear upon your body. ${ }^{31}$

40. (16b) It is a talisman against alcohol. ${ }^{32}$

\section{Talismans based on Tibetan letters and figures}

Alongside with talismans of Chinese origin, those based on Tibetan Buddhist symbols were also widespread among the Mongols.

${ }^{18}$ Mong. yerü gerün ayima $\gamma$-un vuu ene bui.

${ }^{19}$ Mong. ger barayan-u vuu ene bui.

${ }^{20}$ Mong. yalun vuu ene.

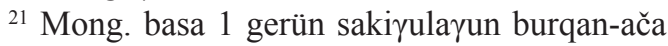

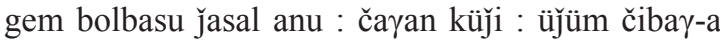

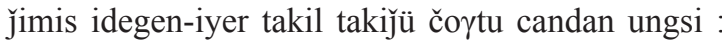
vuu ene bui.

${ }^{22}$ Mong. burqan-i vuu ene bui.

${ }^{23}$ Mong. sibarun-u vuu bičijü bey-e-du qada.

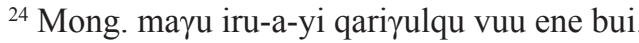

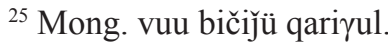

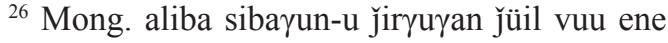
bui.

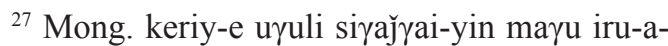
yi qariyulqu vuu ene bui. bui.

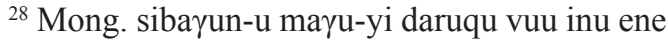

${ }^{29}$ Mong. sidü qabirbasu daruqu buu.

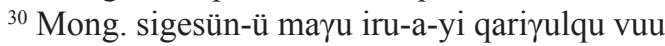
ene bui.

31 Mong. bey-e-dür jegüü. The text gives explanation that this talisman is against women who had buried 7 husbands.

${ }^{32}$ Mong. arikin-u vuu ene bui.
This kind talisman against wolves was described by Hungarian Scholar G. Kara [Kara 2005: 198]. The work of Gombojab can prove that. A manuscript without a title is stored at Damdinsuren's memorial flat [Bilguudei, Otgonbaatar, Tsendina 2018: No. 901]. The author of the work is a famous Mongolian historian and writer Gombojab (1670-1750) who created monumental works on the history of Buddhism in China (Tib. rGya nag chos 'byung), the Mongolian history (Mong. Гangya-yin urursqal) and also numerous treaties on traditional medicine. His treaties are about popular, folk methods of curing diseases. So, talismans presented in his works are aimed to cure different diseases. These are solely tablets with Tibetan signs and figures. Below are the examples.

(1b)

\begin{tabular}{|l|l|l|l|l|}
\hline na $^{33}$ & ma & ta & pa & sha \\
\hline ma & ta & pa & sha & na \\
\hline ta & pa & sha & na & ma \\
\hline pa & sha & na & ma & ta \\
\hline sha & na & ma & ta & pa \\
\hline
\end{tabular}

If you write it on a swelling or stick the writing on it, the disease will abate. If you put the writing into the water and drink it, any inner tumor will soon be gone. ${ }^{34}$

(2a)

\begin{tabular}{|l|l|l|}
\hline 1 & 9 & 4 \\
\hline 6 & 5 & 3 \\
\hline 9 & 1 & 2 \\
\hline
\end{tabular}

Draw it and show it to a woman. Let her know each one of the nine figures, then put the drawing into the water and make her drink a bit. Use the rest of the water to pour upon her from the top beginning from her head, and she will give birth quickly. ${ }^{35}$

${ }^{33}$ The diagram gives letters of Tibetan script.

${ }^{34}$ Mong. aliba qabudar-tur degere inu jiruqu buyu jiru $\gamma=$ san-i ni $\gamma$-a=basu darui amurliqu doturaki

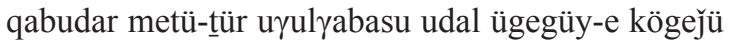
yaryayu.

${ }^{35}$ Mong. egüni jiruyad tere $<\ldots>$ eke nar-tur $\ddot{u}<_{\ldots}>$ lun yisün öriy-e-yi nige nige todurqay-a

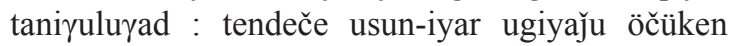

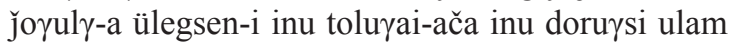
tüsürbesü qurdun könggejeyü.

${ }^{36}$ All letters are written in Tibetan. 


\begin{tabular}{|l|l|l|}
\hline $\mathrm{ma}^{36}$ & li & dhi \\
\hline sha & ma & sa \\
\hline ya & ma & ma(?) \\
\hline
\end{tabular}

Or write it and stick under the navel. That will provide easy and quick delivery. ${ }^{37}$ (2b)

\begin{tabular}{|l|l|l|}
\hline 1 & & 20 \\
\hline 18 & 3 & \\
\hline 12 & 2 & 60 \\
\hline
\end{tabular}

Salt from a salt-marsh, sandalwood, camphor, silh (?), aloe, hemp, saffron, hyarvan (?) - use these eight fragrant substances to write figures in this table, fumigate it with these eight fragrances and hang it upon animal's head. It's the best magic to avoid trouble. ${ }^{38}$

\section{Sa yig}

The above mentioned talismans belong to so called sa yig group (from Tib. sa yig 'inscription, sign'; or bza' yig 'inscription to be eaten'). This is a special group of talismans consisting of dharani or some other magic combinations of symbols and letters which should be eaten in case of a disease or danger. Another manuscript from Otgonbaatar's collection (2 sheets 20x8, Russian paper, black Indian ink, no title, no pagination) written in Mongolian and Tibetan script, contains pictures together with explanations of sa yig. Here are some examples:

(1a) Om Akra maha saka saha. If you roll it and swallow, it will help to relieve passing urine.

Habraabaa hapraapaa habraa habraa haathaa. Eat this if spirits (lus) have done harm to you.

Radza hrim raya pad. Sa yig to be eaten in case of swelling.

Gahu gahu gahu. To be eaten from eyes disease.

Saahaa salahaa saatha. To be eaten from wall-eye.

Damayu thammayu thumanayu. To be eaten from senseless talks.

Hagaa haahaa haabaa. Won't be any raw.

${ }^{37}$ Mong. esebesü egüni bičiged küisün dor-a nirabasu darui könggiči=yü.

${ }^{38}$ Mong. quǰir čandan kiged gabur silh : agaru jayar gürgüm kirvang ene naiman ünür-iyer ene gürtün-i üilesün-dür bičiged mön-kü sayin ünürten-i sürčijü aduүusun-u oroi-dur jegülgebesü yamsi $\gamma$ tasulaqu erkim ubadis bui :
Thaalaa bahaa haatha haatha. To be eaten from abscesses.

Yapahaamaa lapamanaa magramaa moomhaa. Eat it to cure contagious cold.

Omaasaa Abhaa Ahahaahaa. Eat it up to get placenta out.

Haasaa haahra haahra haahra. To be eaten from ticks.

Om a ka se byi ka se mahaa ka se ye sva haa. This sa yig should be eaten in case of heavy breathing. ${ }^{39}$

\section{Dara-Ehe's Key}

In the previous text we have mentioned the talisman which should be given to a woman to ease delivery. There also existed a special picture for the purpose - so called 'Dara-Ehe's Key' (Tib. sgrol ma'i lde mig; Mong. Dara eke-yin tülkigür). It depicted a kind of a labyrinth. Woman had to pass her finger over it to find the exit. Then the fetus was supposed to get out easily. It should be mentioned that such talismans existed mostly as printed ones [Kara 2005: table IX].

\section{Conclusions}

Here we have mentioned only two collections of Mongolian manuscripts to present some examples of talismans which the Mongols used in their daily life. However, these can be

39 (1a) (Tib.) Oṃ Akra spa maha saka saha :

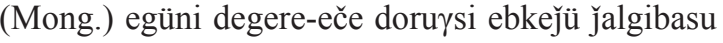

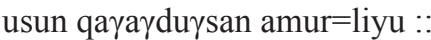

(Tib.) habrābāā hāprāpāā habrāā hābrā hāthā (Mong.) luus-ača boluysan-du ide

(Tib.) radza hrim raya phaț : (Mong.) qadqaqui ebečin-dü idekü sai $\gamma$-a dü ide

(Tib.) gahu gahu gahu (Mong.) nidün-ü ebečin-

(Tib.) sāhā salahā sāthā (Mong.) nidün-ü čayan ide

(Tib.) damayu thammayu thumanayu (Mong.) demei dongrud=qudu ide

(Tib.) hag $\bar{A}$ hāhā hābā (Mong.) kele ama ügei bolqu

(Tib.) thālā bahā hātha hātha (Mong.) boyumadu ide

(Tib.) yapahāmā lapamanā magramā mōṃhā (Mong.) yama-du ide

(Tib.) Oṃāsā Abahā Āha Ahahāhā (Mong.) qoyidu sayada=qudu ide

(Tib.) hāsā hāhra hāhra hāhra (Mong.) yambar=ba qačig-tü ide

(Tib.) Oṃ A ka se byi ka se mahā ka se ye sā

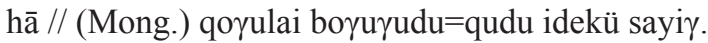


used to draw certain conclusions. All written works of this group demonstrate heterogeneity of traditions which they resembled. Like other spheres of Mongolian culture, they represent pre-Buddhist, Buddhist and Chinese layers. It was conditioned by the history of the Mongols, their neighborhood with civilizations they had been integrated with during the course of their existence. As a result, the ritual life of the Mongols assembled Hindu, Tibetan pre-Buddhist, Buddhist, Mongolian pre-Buddhist, Mongolian Buddhist and Chinese elements in different combinations. Those created complicated multi-layer patterns accepted and implemented by the Mongols.

In pre-Buddhist era, the Mongols mostly used magical talismans by 'word of mouth practice'. This practice still remained popular even when Buddhism appeared and various treaties on the theme (usually of Tibetan and Chinese origin) became widespread. Therefore, there existed two parallel 'cultures' among the Mongols in this sphere: written and verbal ones. It is noteworthy that these two either hardly ever intersect or intersect negligibly. There was scarcely any transmission of one layer into the other as well as borrowings from each other. For example, there was a popular belief among the Mongols that needles and other sharp items can avert evil forces and protect people and their dwellings from harm. Therefore, sharp items (hedgehog's skin, a handsaw or scissors) were fixed over a yurt, hedgehog's needles were sewn up into the clothes, etc. However, examined manuscripts and printed books contain virtually no mentions of such a custom.

The Indian component which was a result of spreading Buddhism among the Mongols, (late $16^{\text {th }}$ - early $17^{\text {th }}$ cent.) can be seen in different protective talismans containing a number of Indian dharani, combinations of Hindu and Buddhist symbols (i. e. swastika) [Bennigsen 1912].

Buddhism is known to have come to Mongolia in a Tibetan form, and no wonder that the Tibetan influence upon shapes and kinds of talismans in Mongolia was dominating. 'Booklore' talismans discovered belong to a rather archaic Tibetan layer, later more or less assimilated by the Buddhist tradition. In the later tradition, the function of protecting human's life was transmitted to Buddhist gods and Buddhist prayers.
And now about Chinese elements in talismans and texts describing them. The Taoist influence is obvious here. Chinese Taoist talismans (Chin. $f u$ 符, Mong. bu, buu, vuu) [Torchinov 2007; Benebell Wen 2016; Yin Zhang 2018] have been found in Mongolian manuscripts since rather early times. In a birch bark manuscript (supposedly $16^{\text {th }}$ cent. stored at the Russian State Archive of Ancient Documents), in the prayer to Avalokiteshvara, one can read an expression repeated several times: 'Here is a talisman and $\operatorname{tarni}^{40}$ devoted to Honsim-Bodisong" ${ }^{\prime 11}$ (12-a-14a). It is supplied with a typical picture of talisman [Otgonbaatar, Tsendina 2008: 200-201, 222-224]. Thus, we can see that talismans like that were known in Mongolia long ago, before the latter's annexation to the Manchu Qing Empire (1644). It is also proved by Mongolian tamga (brand) based on Chinese magic symbols which were often used in talismans [Kara 2005: 160-161].

However, it is not so easy to answer the question how these Chinese elements appeared in Mongolian books and rites. Certainly, household business and other contacts between Mongols and Chinese had always been intensive throughout their history. They became especially close during the Mongol Empire (1260-1360) when the Mongolian dynasty Yuan ruled China, and during the Qing Empire (1644-1911) when Mongolia became part of the latter. In this period, the influence of Chinese economy, mode of life, arts, written tradition was extremely great. This sphere also included their conception of world structure, religion and rites. Due to the above mentioned it seems obvious how Taoism and other Chinese cults penetrated into the Mongols' life. And still it is not quite so. Part of them - primarily talismans and life protecting rites - came to Mongolia not from China directly but were mediated by Tibetan written tradition.

We know that in Tibetan culture, especially at the early stage of spreading Buddhism $\left(7^{\text {th }}-\right.$ $9^{\text {th }}$ cent.), the Chinese component occupied a great place. It seems to be then that many ritual customs, beliefs, types of magic and mantic of Chinese origin, particularly talismans, were accepted. During the following centuries these were supplemented with translations of var-

\footnotetext{
${ }^{40}$ Mongolian pronunciation of dharani.

${ }^{41}$ Mong. qonsim bodisug-un buu inu tarni ene
} bui. 
ious Chinese treaties into Tibetan. Old cults and texts were assimilated by the later Tibetan tradition, sometimes without wording, sometimes being changed by Gelug doctrine or other 'new' Buddhist schools. But the fundamentals, supposedly, were laid exactly at the time of the Tibetan Empire in the $7^{\text {th }}-9^{\text {th }}$ centuries AD.

Such multilayer structure assumes some elements of Mongolization. They do exist, indeed. Thus, despite obviousness of the Chinese origin of ' $b u$ ' talismans, they have letters of

\section{References}

Banzarov 1955 - Banzarov D. Black faith: Or Shamanism among the Mongols. In: Banzarov D. Collected Works. Moscow: USSR Academy of Sciences. Pp. 48-100. (In Russ.)

Bawden 1958a - Bawden C. R. Astrologie und Divination bei den Mongolen - die schriftlichen Quellen (Astrology and divination among Mongols: written sources). Zeitschrift der Deutschen Morgenländischen Gesellschaft. 1958. Vol. 108. Pp. 317-337. (In Germ.)

Bawden 1958b - Bawden C. R. On the practice of scapulimancy among the Mongols. Central Asiatic Journal. 1958. Vol. IV. No. 1. Pp. 1-44. (In Eng.)

Benebell 2016 - Benebell Wen. Tao of Craft: Fu Talismans and Casting Sigils in the Eastern Esoteric Tradition. Berkley: North Atlantic Books, 2016. 616 p. (In Eng.)

Bennigsen 1912 - Bennigsen A. P. Legends and Folktales of Central Asia Collected by Graf A. P. Bennigsen. St. Petersburg, 1912. 168 p. (In Russ.)

Bilguudei, Otgonbaatar, Tsendina 2018 Bilguudei G., Otgonbaatar R., Tsendina A. Catalogue of Mongolian Manuscripts and Xylographs from Ts. Damdinsuren's Memorial Flat. Ulaanbaatar: Soyombo Printing, 2018. 620 p. (In Mong.)

Birtalan 2003 - Birtalan A. Ritualistic Use of Livestock Bones in the Mongolian Belief System and Customs. In: Altaica Budapestinensia MMII. Proceedings of the $45^{\text {th }}$ Permanent International Conference (Budapest, June 23-28, 2002) / ed. A. Sárközi, A. Rákos. Budapest: Akadémiai Kiadó, 2003. Pp. 34-62. (In Eng.)
Tibetan and Mongolian script, Tibetan figures, Hindu and Buddhist symbols, Buddhist mantra ' $u$ ma hum' written in Mongolian script. It denotes that the process of including Taoist symbols of life protecting magic into the TibetanMongolian paradigm was on in Mongolia.

Many of these 'booklore' talismans and traditions of using them to avert evil forces are still alive nowadays, though their sphere of application is getting narrower and their types are being transformed due to global changes.

Cerensodnom 1997 - Cerensodnom D. Mongolian Literature of Buddhism. Vol. 1. Ulaanbaatar: Mongolian Academy of Sciences, 1997. (In Mong.)

Gerasimova 1999 - Gerasimova K. M. Life Protecting Rites in Central Asian Buddhism. Ulan-Ude: Buryat Scientific Center (Sib. Branch of RAS), 1999. 159 p. (In Russ.)

Kara 2005 - Kara G. Books of the Mongolians Nomads: More Than Eight Centuries of Writing Mongolian. J. R. Krueger (transl.). Bloomington: Indiana University, 2005. 371 p. (In Eng.)

Otgonbaatar, Tsendina 2008 - Otgonbaatar R., Tsendina A. Mongolian birch bark manuscripts from the Russian State Archive of Ancient Documents. In: Tsendiin Damdinsuren. Celebrating the $100^{\text {th }}$ Anniversary of Birth. Moscow: Vostochnaya Literatura, 2008. Pp. 192-235. (In Russ.)

Sazykin 1988 - Sazykin A. G. Institute of Oriental Studies, USSR Academy of Sciences: Catalogue of Mongolian Manuscripts and Xylographs. Vol. 1. Moscow: Nauka, 1988. 511 p. (In Russ.) Torchinov 2007 - Torchinov E. A. Taoism: The Path to Immortality. St Petersburg: Peterburgskoe Vostokovedenie, 2007. 608 p. (In Russ.)

Wen 2016 - Wen B. Tao of Craft: Fu Talismans and Casting Sigils in the Eastern Esoteric Tradition. Berkley, California: North Atlantic Books, 2016. 600 p. (In Eng.)

Yin Zhang 2018 - Yin Zhang. Combating illnesscausing demons in the home: fabing treatises and their circulation from the Late Ming through the Early Republican Period. Late Imperial China. 2018. Vol. 39. No. 2. Pp. 59-108. (In Eng.) 

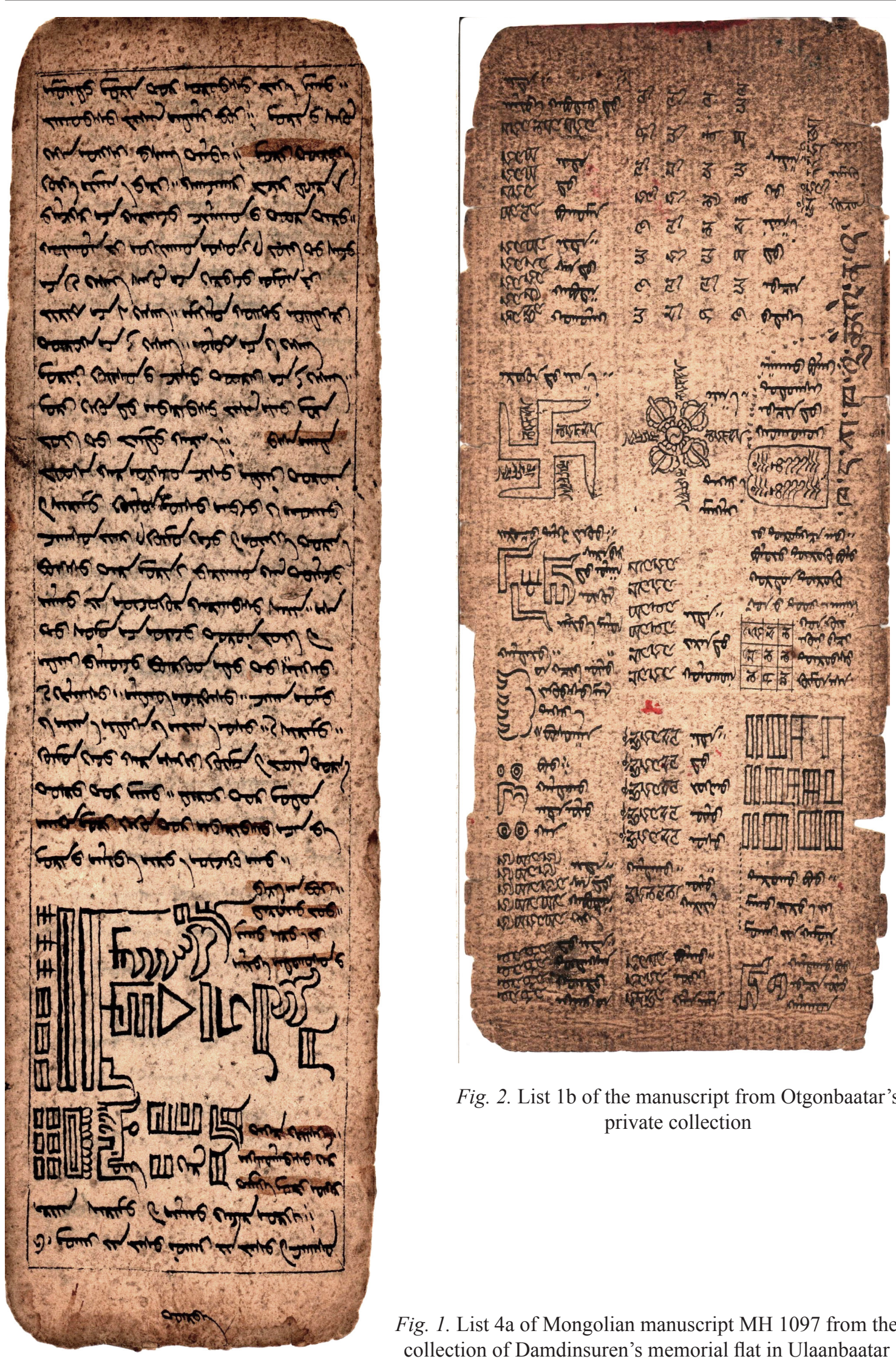

Fig. 2. List $1 \mathrm{~b}$ of the manuscript from Otgonbaatar's private collection

Fig. 1. List 4a of Mongolian manuscript MH 1097 from the collection of Damdinsuren's memorial flat in Ulaanbaatar 


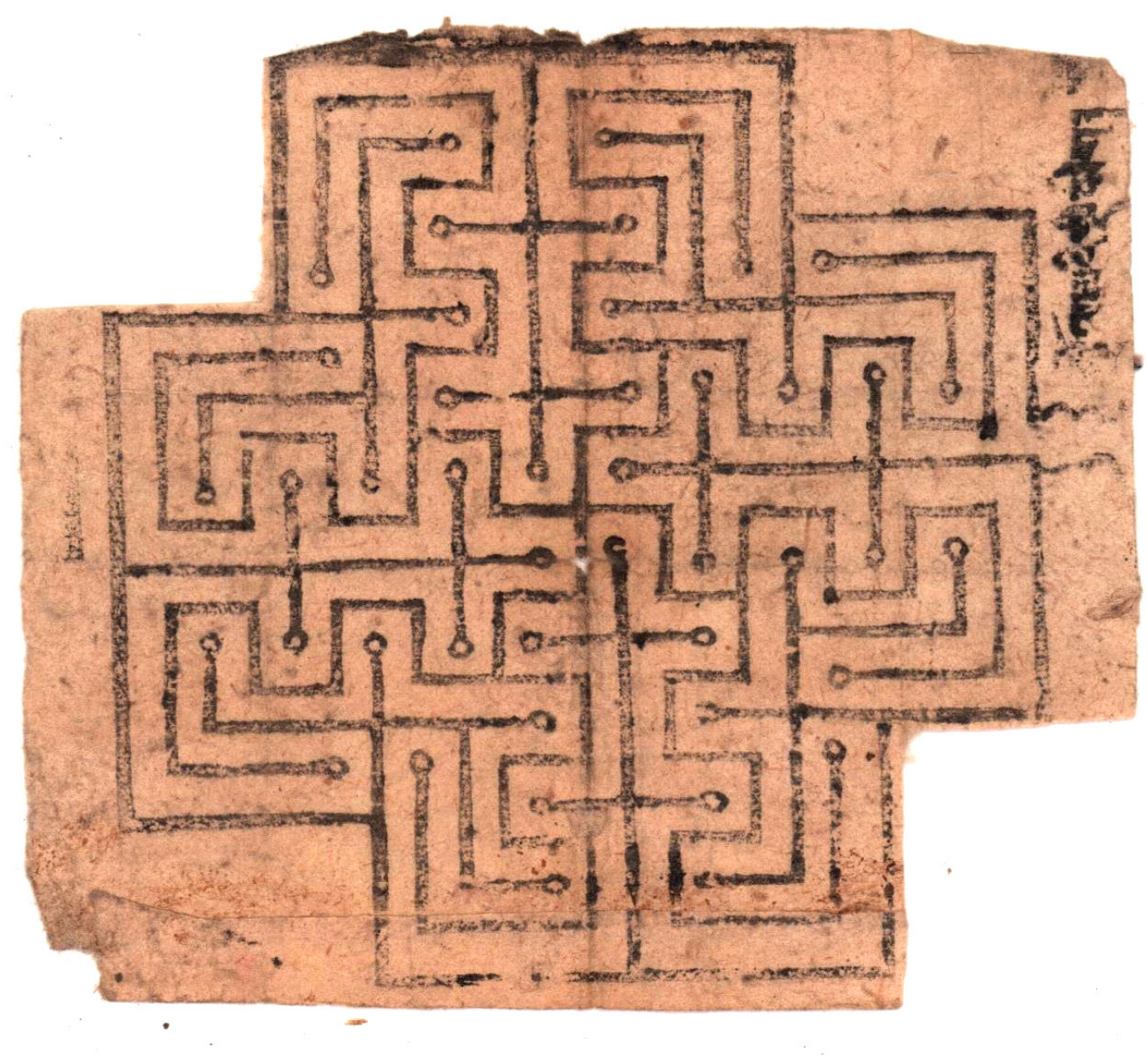

Fig. 3. Dara-Ehe's Key' from Otgonbaatar's private collection 